\title{
Improving Innovation in University Spin-Offs. The Fostering Role of University and Region
}

\author{
Christian Corsi ${ }^{* 1}$, Antonio Prencipe ${ }^{1}$
}

\begin{abstract}
University spin-offs (USOs) are companies created to commercialize knowledge or technology developed in academia; thus, their major contribution to the knowledge economy is their ability to generate innovation. Following the Resource-Based View of the Firm and the Knowledge Spillover Theory of Entrepreneurship, it was stated that fostering mechanisms at university level and at regional level may positively influence the USOs innovation. Based on a sample of 621 Italian USOs, we show that the positive impact of the university context is more crucial compared with those of the regional context. In particular, the university affiliated business incubators and Science Parks, jointly with the university financial resources, seem to promote the innovation efforts of USOs. These evidences rise the need of a resilient partnership among all the contextual players involved in the spillover processes, mainly at regional level, in order to effectively exploit the potential innovative efforts of the university start-ups.
\end{abstract}

Keywords: University spin-offs; Innovation; University context; Regional context; Knowledge Spillover Theory; Resource-Based View

Submitted: $\quad$ March $6^{\text {th }} 2016 /$ Approved: June $9^{\text {th }} 2016$

\section{Introduction}

In the last decade, the interest of scholars in the dynamics of growth and mechanisms that promote university entrepreneurship, through University Spin-Offs (USOs), has improved (Fini et al., 2011; Sternberg, 2014; Rodeiro-Pazos et al., 2012). Indeed, these university start-ups are an effective tool in inspiring the establishment and development of knowledge-based economies (Sternberg, 2014). The determining factor related with their creation and growth have become strategic and vital matters in the policy actions concerning the dissemination and promotion of innovation in specific environmental contexts (Lockett et al., 2005). Indeed, the USOs are companies created with the aim to commercialize knowledge or technology developed in academia; therefore, their major contribution to the knowledge economy is their ability to generate innovation (Rodríguez-Gulías et al., 2015). Additionally, the contribution of innovation to growth has been well recognised in literature, both in theoretical and empirical perspective, becoming a pivotal and strategic element (Wong et al., 2005). Several studies emphasise that USOs usually have got a better performance in term of innovative activities in comparison with non-academic start-ups, especially in term of patent generation (Cantner \& Goethner, 2011; Lejpras, 2014), pointing out as its original nature of academic environment significantly affects the innovation direction and dynamics of the spillover company. Nevertheless, other scholars reveal that USOs are no so effective in generating innovation, with a small impact in the socio-economic environment (Rodeiro-Pazos et al. 2014; Iacobucci \& Micozzi, 2014). These considerations call for a more understanding of the fostering factors and mechanisms which encourage innovation activities in USOs. In this regard, the theoretical assumption of the resource-based view theory applied to the USO context (Rodeiro-Pazos et. al, 2012; Vinig \& Van Rijsbergen, 2010) and the Knowledge Spillover Theory of Entrepre- neurship (Acs et al., 2013) remarks the resources, capabilities and fostering mechanisms of university origin (Rasmussen et al., 2014), jointly with the features, the composition and the interactions of the regional context in which the USO is located (Sternberg, 2014; Rodríguez-Gulías et al., 2015) in supporting entrepreneurship activities, such as innovative ones. The assumptions above mentioned acquire a greater cognitive and exploratory value if we consider that innovation activities and outcome in USOs context have not been fully investigated, and only recently some scholars are contributing to explore some relevant issues regarding the innovative dynamics of academic entrepreneurship (Rodríguez-Gulías et al., 2015; Cantner \& Goethner 2011; Lejpras 2014). Nevertheless, Cantner and Goethner (2011) and Lejpras (2014) have adopted a firm-centred approach in the investigation of the innovative performance of USOs, while only Rodríguez-Gulías et al. (2015) have adopted an interactionist approach, including the promoting role of the regional context in the study of USOs innovation. This study aims to enrich the knowledge gained with the cited studies in a complementary and cross manner through a two-level contextual approach of analysis: the university level and the regional level. The approach it was extensively used to investigate the success determinants of USOs in term of number of generated firms and firm performance (Rodeiro-Pazos et al., 2012; Fini et al., 2011), but never in term of innovativeness of the USOs. Hence, this paper aims to fill this knowledge gap in the USOs literature by hypothesizing that the university context and the regional context may partially determine the innovative performance of USOs. To this purpose, the study analyses a sample of 621 Italian USOs in 2014. Italy is one of the major European countries reporting a rapid expansion of the university spin-off phenomenon (Fini et al., 2011; Iacobucci \& Micozzi, 2014). Indeed, according to the latest report Netval (Netval, 2015), at 31.12.2014, the spin-offs, by a public research surveyed in Italy are 1102 and that about $87.4 \%$ of them has been formed over

(1) Università degli Studi di Teramo, Teramo, Italy

*Corresponding author: ccorsi@unite.it 
the past ten years. The paper aims to provide a contribution to the knowledge - both in term of academic and managerial perspective about the mechanisms fostering innovation in USOs, with reference to emerging contextual critical factors by applying multilevel analysis. Similarly, the paper wants to improve the understanding about the technology transfer activities and the related most suitable policy actions to rise their success and development, with the purpose to contribute to the economic diffusion of innovation, driving of the firm and economic growth.

\section{Theoretical Background}

\section{University context and USOs innovation}

There are several methods and mechanisms that can be engaged by universities to fostering innovation through spin-out processes. Following the theoretical arguments of the Resource-Based View of the Firm (Sirmon et al., 2007), which focuses on distinctive recipes of resources and capabilities, the effectiveness of spin-out processes and innovative activities by USOs (Rodeiro-Pazos et. al, 2012; Vinig \& Van Rijsbergen, 2010) is closely linked to the financial assets, human capital, organizational and technological resource factors from the university (Rasmussen et al., 2014).

\section{The role of technology transfer office (TTO)}

Universities can foster technological innovation of USOs by establishing technology transfer offices (TTOs). Indeed, TTOs support technological diffusion by the licensing to industry of inventions or intellectual property generating in academia (Algieri et al., 2013). The innovation management literature argues that commercial resources provided by the TTOs have a complementary but significant role for the appropriation of research outputs and for improving innovative activities in academic entrepreneurship (O'shea et al., 2005). In order to spread innovative findings, TTOs support researchers encourage and control the university's intellectual property, contributing to create networks among academicians and venture capitalists, as well as with the industry (Berbegal-Mirabent et al., 2015), stimulating the financing and management support of the innovative activities of USOs with the sharing of vital tangible and intangible resources. In this regard, TTO staff facilitates innovation thanks to their better knowledge about technology and their marketability (Plewa et al., 2012) and TTO personnel skills are pivotal for the spinout process (Wood, 2011). For this reason, we constructed the following hypotheses:

H1a: There is a positive relationship between the number of TTO staff and the innovation performance of USOs.

\section{The role of the university incubators and Science Park}

University-affiliated business incubators are central actors in the value creation process of USOs (O'Shea et al., 2005; Berbegal-Mirabent et al., 2015). Indeed, literature remarks the vital support of these infrastructural fostering mechanisms of university entrepreneurship, especially during the early stage of USOs (Grimaldi \& Grandi, 2005). Incubators accelerate the knowledge and technologies exploitation giving advanced professional facilities in the form of human skills, expertise, supporting infrastructure at the young university start-ups, reducing the gap between academia and industry and improving the growth and innovative directions of the firm (Etzkowitz, 2002). In this regard, the university incubators help the entrepreneur to overcome technical, management and market barriers for the full development of the innovative activities of the spin-off (Vinig \& Van Rijsbergen, 2010).

H1b: There is a positive relationship between the existence of incubation services in the university and the innovation performance of USOs.

Another form of fostering support to the development and innovation of USOs is the university-affiliated science park (Minguillo et al., 2015). Indeed, Science Park are entrepreneurial organizations where knowledge spillovers could rise more simply among the universities and spin-offs, fostering the creation and exchange of technology and knowledge between them (Montoro-Sánchez et al., 2011). Therefore, USOs inside Science Parks may improve their innovative ability by linking their internal expertise with the knowledge provided by the parent organization, jointly with those derived by located firms (Díez-Vial \& Montoro-Sánchez, 2015). University Science Parks are vital hubs that encourage and control the flow of knowledge and technology among academic institutions, supporting the development and growth of innovation-based companies, such as USOs. Hence, University science parks make available an idyllic milieu to generate, exploit and share knowledge and technological capability among all actors involved. These parks provide knowledge-building working area, generate business clusters, improve the efforts and the output of universities research policies, as well as bring high-tech companies and science-based business together, to better perform in the modern knowledge economy (Berbegal-Mirabent et al., 2015).

H1c: There is a positive relationship between the existence of university science parks and the innovation performance of USOs.

\section{The role of university financial resources in research activities}

An essential prerequisite for the start of technology transfer and, thus, for the optimal generation of innovation from university spin-offs, is the level of financial resources available in research activities (Declercq, 1981). The role of resources in R\&D activities is central in encouraging innovative performance of USOs, providing the capability to engage external knowledge and be more innovative (RodríguezGulías et al., 2015). About this aspect, some scholars have revealed that the university spin-offs activity and performance are positively related with the stock of research funding provided by the parent organizations (Van Looy et al., 2011). Indeed, the university research activity is pivotal in the success performance of the spin-off firms therein generated, because the higher the volume of university research activity, the higher the volume of technology to be exploited, which is directly associated to the university financial resources in research activities (Rodeiro-Pazos et al., 2012).

H1d: There is a positive relationship between the university financial resources in research activities and the innovation performance of USOs. 


\section{Regional context and USOs innovation}

Several scholars remark the pivotal role of the geographical dimension and proximity in the understanding of the innovation process (Gittelman, 2007). Indeed, regional context has been recognised as a central argument for knowledge generation, in the current knowledge of economy (Florida, 1995), especially concerning the firm innovation (Audretsch \& Feldman, 2004). In this view, the Knowledge Spillover Theory of Entrepreneurship is useful to clarify the level of entrepreneurial innovation system of a region (Plummer \& Acs, 2014), as combining investments in knowledge by the universities to those by the regions, becoming suitable to evaluate the extent of entrepreneurial activity related to the universities (Acs et al., 2013). Hence, USOs can take advantage from the knowledge capability of a region and from other dynamics linked to the local spatial externalities (Guerini \& Rossi-Lamastra, 2014).

\section{The role of the regional $R \& D$ activities}

The regional knowledge infrastructure is one of the central element in the knowledge/technology spillovers, stimulating innovative activities (Beugelsdijk, 2007). The regional knowledge infrastructure is a combination of R\&D workforces and expenditures, jointly with other complementary elements (Fini et al., 2011; Audretsch \& Feldman, 2004). In line with this consideration, external R\&D activities can act as input for USOs (Raspe \& Van Oort2009), which can benefit from the results achieved by the regional innovative efforts. This is in view of the mid-term effect from which high-tech firms can take advantage, element linked to the so-called spillover effect (Acs et al., 2013). These arguments are in line with the classic theoretical and empirical works that state a positive association between R\&D and innovative outputs of the firm (Audretsch, 2003).

$H 2 a$ : There is a positive relationship between the regional R\&D expenditure and the innovation performance of USOs.

$H 2 b$ : There is a positive relationship between the regional human resources in R\&D and the innovation performance of USOs.

\section{The role of the regional human capital}

Additionally, the literature stressed as the formation and development of human capital, with specialized skills in the regional context, is a central source of external knowledge for the innovative activities high-tech start-ups, such as USOs (Audretsch \& Feldman, 2004). The basic reason of the above-mentioned concept is linked to the argument that a well-educated labour force has several chances to absorb and use information and learning, thus understand, in a potentially systematic way, the complex dynamics of the socio-economic system, becoming a strategic feature of the regional knowledge economy (Raspe \& Van Oort, 2008). Nevertheless, Florida (2005) claims that the geographic link from education to innovation output, in that same regional context, may no longer hold. This is due to the improved mobility of highly skilled and educated individuals within nations and even across borders. However, the human capital of a region remains crucial for a USO as its educational context of origin leads to keep and absorb the best-qualified and skilled regional workforce (Rodríguez-Gulías et al., 2015).

H2c: There is a positive relationship between the regional human capital and the innovation performance of USOs.

\section{The role of the regional patenting activity}

A key factor, associated to innovation performance of academic spinoffs, is represented by the innovation capacity of the region (Sternberg, 2014). The literature usually employs the patenting activity as an indicator of the technical knowledge of a region (Audretsch et al., 2008), and as a location of a spin-off, in an active region, it may bring benefits to the entrepreneurial development of intellectual property, generated therein and thereby, contributing to the entrepreneurship and innovation effort (Griliches, 1990). Furthermore, external patenting activity may potentially function as input for other firms due to the imitative behaviour of competitors (Van Oort \& Raspe, 2009). Consequently, the innovative performance of USOs can be associated to external innovation of the regional entrepreneurial context.

H2d: There is a positive relationship between the regional patenting activity and the innovation performance of USOs.

\section{Method}

\section{Sample}

In order to test the research hypothesis above, it was analysed a panel sample of 621 Italian USOs extracted from Netval database at 31 December 2014, a database part of the project "Spin-off Italia" and run in collaboration with Netval, Università Politecnica delle Marche and Scuola Superiore Sant'Anna - Istituto di Management, which collect updated information about the full population of active spin-off in Italy; while data cover a period from 2004 to 2012. Additionally secondary data about USOs was performed by the analysis of financial statements and other corporate files extracted from Aida BdV database, an Italian subset of ORBIS database, which containing historical financial, biographical and merchandise data of about 700,000 Italian active companies. Precisely, financial information are provided by Honyvem who acquire and reprocesses all official accounts deposited with the Italian Chambers of Commerce. Information regarding the regional context were collected by extracting data from the records stored by the Italian National Institute of Statistics (ISTAT) and the Statistical Office of the European Communities (EUROSTAT), while data concerning the patent activity of universities were extracted from PATIRIS database. Lastly, data regarding university research funding, business incubators and Science Parks were collected from institutional websites of universities, MIUR (Ministry of Education, University and Research) and regional authorities.

\section{Variable definition}

\section{Dependent variable}

The dependent variable applied in this study, the innovation performance USO, was measured by a dummy variable that takes the 
value 1 if the USO had any patent activity and 0 otherwise (INNOVATION). Indeed, the patent is one of the major output of companies' ideas and novelty, representing a key milestone within the innovative activities of the spin-off. In addition, patenting activity is usually used to measure the innovation performance in spin-out process (Lejpras, 2014; Rodríguez-Gulías et al., 2015).

\section{Independent variables}

With the aim to predict the potential effects of the selected two-level contextual determinants, of innovation performance of USOs, three independent key variables are used in the multivariate analysis. Regarding the university context variables, according to Rodeiro-Pazos et al. (2012) and Vinig and Van Rijsbergen (2010), the technology transfer office support is measured by the number of full-time equivalents (FTEs) employed in the TTO (TTO STAFF). Second, in line with Berbegal-Mirabent et al. (2015), with the aim to evaluate the impact of the infrastructural support to innovation by university incubators and Science Parks, it has been used the number of university-affiliated business incubators (UNI INCUBATOR) and Science Parks (UNI SCIENCE PARK). Third, following Fini et al. (2011), we addressed university financial resources for research eminence by coding the amount of public research fund (in Euro units), which is part of the ordinary funding (FFO), a government funding that constitutes a major source of income for Italian universities (UNI R\&D). With reference to the regional context variables, with the aim of estimating the prominence research resource of a region and, hence, the knowledge spillovers in the local context, it has been used, in line with Fini et al. (2011), a variable, stating the public R\&D expenditure in the administrative region in thousands of Euros (REG R\&D EXPEND); jointly with a variable, following Audretsch and Keilbach (2004), which measures the amount of regional personnel and researchers employed in R\&D activities (REG R\&D STAFF). In order to evaluate the human capital eminence of a region, it has been used a variable, stating the number of persons with tertiary education and/or employed in science and technology at regional level (REG HUMAN CAPITAL). Finally, in accordance with Baldini (2010), regional patenting activity - with particular reference to the entrepreneurial and competitive context of spin-offs - is measured by the high-tech patent applications to the European Patent Office in each region (REG PATENT).

\section{Control variables}

In line with Sørensen and Stuart (2000), it is control for the number of years that the USO has been active (AGE), jointly with the firm size, in accordance with De Cleyn and Braet (2012), determined by the number of USO's employees (SIZE). Following Berbegal-Mirabent et al. (2015), it is control for the effects of USO' industry, by a dummy variable for USOs in high-tech industries (HIGH-TECH) which takes the value 1 if the USO operates in high-tech industries and 0 otherwise. Since the success performance of USOs may be associated to the number of inventions generated by the university (O'Shea et al., 2005), it is control for the stock of patents for each university in the last 10 years (PATENT).

\section{Analytical approach}

In order to test research hypothesis it has been used a binary probit GLM in the estimation of parameters, which is extremely useful in case of dichotomous dependent variables (Pardo \& Pardo, 2008). The use of ordinary least square (OLS) regression is inappropriate for this type of dependent variables because the possible range of values is confined to two sides of the interval [0-1] (Kieschnick \& $\mathrm{McCu}$ llough, 2003). Additionally, this statistical method is designed for a maximum-likelihood estimation of the number of rates of non-negative counts.

\section{Results}

\section{Univariate analysis}

Table 1 shows the descriptive statistics of the variables used in the models. The results indicate that the sampled USOs show a low degree of innovation performance, with a mean value of $1.9 \%$ of patenting activity and a moderate dispersion in the sample (S.D. = $13.77 \%$ ). The number of TTO staff is a sample mean of 5.28 , value this that is quite homogeneous in the sample (S.D. = 2.75). On average, universities show a number of about 1 affiliated business incubators (S.D. $=0.92$ ), while the sample average of university-affiliated Science Park is very low, less than 1 (S.D. = 0.48), indeed the sample universities are linked with no more than one Science Park. Regarding the university financial resources in research activities, results show a sample mean of 13,952,122.41 euro, although these data are highly dispersed in the sample (S.D. $=10,210,624.318$ ). The number of persons with tertiary education and/or employed in science and technology at regional level show a sample mean of 746.90 but with a high-moderate dispersion in the sample (S.D. $=515.20$ ), while the high-tech patent applications to the European Patent Office in each region show a sample mean of 172.80 (S.D. =42.48). The public R\&D expenditure in the administrative region shows an average of 340.199 thousands of Euros (S.D. =151.61), while the amount of regional personnel and researchers employed in $\mathrm{R} \& \mathrm{D}$ activities shows a low sample mean of 1.95 , with a high dispersion in the sample (S.D. $=4.96$ ). Table 2 reports the bivariate Pearson correlations among all variables employed. Given the lack of sufficient high correlation among the independent variables, issues of nonsense correlation are not detected (Aldrich, 1995; Cohen et al., 2013). We checked for multicollinearity, formally using VIF statistics. We found that the VIF scores did not exceed 4.98 which is not close to the rule of thumb "threshold" value of 10 (Hair et al., 1998) - and an average of 1.96; while the "tolerance" level shows an acceptable value higher than 0.10 , suggesting that multicollinearity is not a serious concern, therefore multiple regression analysis can be used to test the hypotheses. It must be specified that our estimation methods, negative binomial regression, do not allow the estimation of VIF scores. Therefore, we report the VIF scores obtained from estimating the models through ordinary least squares (OLS). 
Table 1. Descriptive statistics

\begin{tabular}{|c|c|c|c|c|c|c|}
\hline & $\mathrm{N}$ & Min. & Max. & Mean & S.D. & Variance \\
\hline INNOVATION & 5589 & 0,000 & 1,000 & 0,019 & 0,138 & 0,019 \\
\hline PATENT & 5589 & 0,000 & 408,000 & 93,766 & 94,480 & 8926,389 \\
\hline HIGH-TECH & 5589 & 0,000 & 1,000 & 0,139 & 0,346 & 0,119 \\
\hline TTO STAFF & 5589 & 2,000 & 15,000 & 5,278 & 2,750 & 7,563 \\
\hline UNI INCUBATOR & 5589 & 0,000 & 3,000 & 0,834 & 0,922 & 0,850 \\
\hline REG HUMAN CAPITAL & 5589 & 38,000 & 1902,000 & 746,896 & 515,199 & 265429,704 \\
\hline REG PATENT & 5589 & 0,170 & 172,800 & 39,442 & 42,477 & 1804,326 \\
\hline REG R\&D EXPEND & 5589 & 58,500 & 855,900 & 340,199 & 151,610 & 22985,648 \\
\hline REG R\&D STAFF & 5589 & 0,400 & 71,460 & 1,951 & 4,960 & 24,606 \\
\hline
\end{tabular}

Source: authors

Table 2. Correlations

\begin{tabular}{|c|c|c|c|c|c|c|c|c|c|c|c|c|c|c|}
\hline & & 1 & 2 & 3 & 4 & 5 & 6 & 7 & 8 & 9 & 10 & 11 & 12 & 13 \\
\hline 1 & INNOVATION & 1 & & & & & & & & & & & & \\
\hline 2 & AGE & $0.064^{* *}$ & 1 & & & & & & & & & & & \\
\hline 3 & PATENT & -0.005 & $0.196^{* *}$ & 1 & & & & & & & & & & \\
\hline 4 & SIZE & $0.030^{*}$ & $0.071^{* *}$ & $0.106^{* *}$ & 1 & & & & & & & & & \\
\hline 5 & HIGH-TECH & $-0.056^{* *}$ & $-0.233^{* *}$ & $0.046^{*}$ & -0.007 & 1 & & & & & & & & \\
\hline 6 & TTO STAFF & $-0.050^{*}$ & $0.063^{* *}$ & $0.137^{* *}$ & $0.414^{* *}$ & $-0.062^{* *}$ & 1 & & & & & & & \\
\hline 7 & $\begin{array}{l}\text { UNI } \\
\text { INCUBATOR }\end{array}$ & 0.000 & $-0.033^{\star}$ & -0.013 & $0.267^{* *}$ & $0.046^{* *}$ & 0.028 & 1 & & & & & & \\
\hline 8 & $\begin{array}{l}\text { UNI SCIENCE } \\
\text { PARK }\end{array}$ & $-0.057^{* *}$ & -0.001 & -0.016 & $-0.030^{*}$ & 0.020 & 0.202 & 0.221 & 1 & & & & & \\
\hline 9 & UNI R\&D & -0.001 & 0.004 & 0.009 & $0.575^{* *}$ & $0.035^{* *}$ & $0.067^{* *}$ & 0.288 & $0.085^{* *}$ & 1 & & & & \\
\hline 10 & $\begin{array}{l}\text { REG HUMAN } \\
\text { CAPITAL }\end{array}$ & -0.020 & $0.115^{* *}$ & $0.092^{* *}$ & $0.335^{* *}$ & -0.002 & $0.118^{* *}$ & $0.125^{* *}$ & $-0.069^{* *}$ & $0.247^{* *}$ & 1 & & & \\
\hline 11 & REG PATENT & $-0.031^{*}$ & $0.115^{* *}$ & $0.085^{* *}$ & $0.328^{* *}$ & 0.010 & $0.144^{* *}$ & $0.098^{* *}$ & $-0.106^{* *}$ & $0.201^{* *}$ & 0.802 & 1 & & \\
\hline 12 & $\begin{array}{l}\text { REG R\&D } \\
\text { EXPEND }\end{array}$ & $-0.063^{* *}$ & $0.067^{* *}$ & $0.062^{* *}$ & $0.307^{* *}$ & 0.009 & 0.019 & 0.177 & -0.020 & $0.316^{* *}$ & 0.506 & 0.407 & 1 & \\
\hline 13 & $\begin{array}{l}\text { REG R\&D } \\
\text { STAFF }\end{array}$ & 0.008 & 0.013 & -0.005 & 0.003 & -0.016 & 0.013 & $-0.029^{*}$ & 0.007 & 0.000 & -0.005 & -0.002 & $0.050^{* *}$ & 1 \\
\hline
\end{tabular}

$* * * \mathrm{p}<0.001 ; * * \mathrm{p}<0.01 ; * \mathrm{p}<0.05 ;$ (all two-tailed tests). Source: authors 


\section{Multivariate analysis}

Table 3 shows the results of the binary probit GLM in the estimation of innovation performance of USOs, referring to the university context effects. The regression analyses are performed in a step-wise manner. Model 1 includes all the control variables; Model 2, 3, 4 and 5 refer to the four principle effects, entered one by one, while Model 6 represents the full model. H1a remarks a positive relationship between the number of TTO staff and the innovation performance of USOs. In the Model 2, the estimated coefficient on TTO STAFF is positive but not statistically significant. Thus, these results do not support H1a. H1b states a positive relationship between the existence of incubation services in the university and the innovation performance of USOs. In the Model 3, the estimated coefficient on UNI INCUBATOR is positive and statistically significant (coeff. $=0.311, \mathrm{p}<0.05$ ), so confirming $\mathrm{H} 1 \mathrm{~b}$. H1c indicates a positive relationship between the existence of university science parks and the innovation performance of USOs. In the Model 4, the estimated coefficient on UNI SCIENCE PARK is positive and statistically significant (coeff. $=6.726, \mathrm{p}<0.001$ ), providing support to H1c. H1d states a positive relationship between the university financial resources in research activities and the innovation performance of USOs. In the Model 5, the estimated coefficient on UNI R\&D is statistically significant but irrelevant in practical term (coeff. $=0.000, \mathrm{p}<$ 0.05). Thus, the evidence not allow to confirming H1d.

Table 3. GLM binary probit regression estimation predicting the effect of university fostering mechanism on USO innovation

\begin{tabular}{|c|c|c|c|c|c|c|c|c|c|c|c|c|}
\hline \multirow[t]{2}{*}{ Variables } & \multicolumn{2}{|c|}{ Model 1} & \multicolumn{2}{|c|}{ Model 2} & \multicolumn{2}{|c|}{ Model 3} & \multicolumn{2}{|c|}{ Model 4} & \multicolumn{2}{|c|}{ Model 5} & \multicolumn{2}{|c|}{ Model 6} \\
\hline & B & S. E. & B & S. E. & B & S. E. & B & S. E. & B & S. E. & B & S. E. \\
\hline \multicolumn{13}{|l|}{ Control variables } \\
\hline AGE & $-0.075^{* * *}$ & $(0.0110)$ & $-0.74^{* * *}$ & $(0.0112)$ & $-0.76^{* * *}$ & $(0.0108)$ & $-0.081^{* * *}$ & $(0.0130)$ & $-0.072^{* * *}$ & $(0.0115)$ & $-0.080^{* * *}$ & $(0.0117)$ \\
\hline PATENT & $0.010^{* * *}$ & $(0.0018)$ & $0.010^{\star * *}$ & $(0.0019)$ & $0.011^{* * *}$ & $(0.0018)$ & $0.004^{* * *}$ & $(0.0008)$ & $0.006^{* * *}$ & $(0.0017)$ & 0.000 & $(0.0014)$ \\
\hline SIZE & -0.011 & $(0.0360)$ & -0.011 & $(0.036)$ & -0.012 & $(0.0352)$ & 0.002 & $(0.0413)$ & -0.008 & $(0.0367)$ & -0.005 & $(0.0098)$ \\
\hline HIGH-TECH & $4.889^{* * *}$ & & 4.884 & $(5.4719)$ & 5.044 & $(4.4033)$ & 4.925 & (3.4759) & 4.949 & $(5.1436)$ & $5.534^{* * *}$ & \\
\hline \multicolumn{13}{|l|}{$\begin{array}{l}\text { Hypothesized } \\
\text { effects }\end{array}$} \\
\hline TTO STAFF & & & 0.005 & $(0.0262)$ & & & & & & & -0.081 & $(0.0476)$ \\
\hline $\begin{array}{l}\text { UNI } \\
\text { INCUBATOR }\end{array}$ & & & & & $0.311^{*}$ & $(0.1290)$ & & & & & $0.400^{* * *}$ & $(0.1148)$ \\
\hline UNI & & & & & & & & & & & & \\
\hline SCIENCE & & & & & & & $6.726^{* * *}$ & & & & 6.839 & (12.4309) \\
\hline PARK & & & & & & & & & & & & \\
\hline UNI R\&D & & & & & & & & & $0.000^{*}$ & $(0.0000)$ & $0.000^{*}$ & $(0.0000)$ \\
\hline $\begin{array}{l}\text { Likelihood-ratio } \\
\text { chi-square }\end{array}$ & $55.975^{\star * *}$ & & $55.987^{\star * *}$ & & $60.298^{* * *}$ & & $81.375^{\star * *}$ & & $58.608^{* * *}$ & & $108.545^{\star * *}$ & \\
\hline
\end{tabular}

${ }^{* * *} \mathrm{p}<0.001 ;{ }^{* *} \mathrm{p}<0.01 ;{ }^{*} \mathrm{p}<0.05$; (all two-tailed tests). Source: authors

Table 4 shows the results of the binary probit GLM in the estimation of innovation performance of USOs, referring to the regional context effects. Also in this case, regression analyses are performed in a step-wise manner. Model 1 includes all the control variables; Model 2, 3, 4 and 5 refer to the four principle effects, entered one by one, while Model 6 represents the full model. H2a states a positive relationship between the regional R\&D expenditure and the innovation performance of USOs. In the Model 2, the estimated coefficient on REG R\&D EXPEND is not positive and not statistically significant, thus, not supporting $\mathrm{H} 2 \mathrm{a}$. H2b remarks a positive relationship between the regional human resources in R\&D and the innovation performance of USOs. In the Model 3, the estimated coefficient on REG R\&D STAFF is negative and not statistically significant. Hence, these results do not support $\mathrm{H} 2 \mathrm{~b}$. $\mathrm{H} 2 \mathrm{c}$ indicates a positive relationship between the regional human capital and the innovation performance of USOs. In the Model 4, the estimated coefficient on REG HUMAN CAPITAL is negative not statistically significant; thus, not supporting the $\mathrm{H} 2 \mathrm{c}$. $\mathrm{H} 2 \mathrm{~d}$ states a positive relationship between the regional patenting activity and the innovation performance of USOs. In the Model 5, the estimated coefficient on REG PATENT is negative and not statistically significant, hence, not supporting the $\mathrm{H} 2 \mathrm{~d}$.

Table 4. GLM binary probit regression estimation predicting the effect of regional fostering mechanism on USO innovation

\begin{tabular}{|c|c|c|c|c|c|c|c|c|c|c|c|c|}
\hline \multirow[t]{2}{*}{ Variables } & \multicolumn{2}{|c|}{ Model 1} & \multicolumn{2}{|c|}{ Model 2} & \multicolumn{2}{|c|}{ Model 3} & \multicolumn{2}{|c|}{ Model 4} & \multicolumn{2}{|c|}{ Model 5} & \multicolumn{2}{|c|}{ Model 6} \\
\hline & B & S. E. & B & S. E. & B & S. E. & B & S. E. & B & S. E. & B & S. E. \\
\hline Control variables & & & & & & & & & & & & \\
\hline AGE & $-0.075^{* * *}$ & $(0.0110)$ & $-0.072^{\star * *}$ & $(0.0119)$ & $-0.069^{* * *}$ & $(0.0127)$ & $-0.072^{* * *}$ & $(0.0019)$ & $-0.074^{* * *}$ & $(0.0110)$ & $-0.016^{* * *}$ & $(0.0038)$ \\
\hline PATENT & $0.010^{* * *}$ & $(0.0018)$ & $0.010^{* * *}$ & $(0.0018)$ & $0.010^{* * *}$ & $(0.0018)$ & $0.010^{* * *}$ & $(0.0018)$ & $0.010^{* * *}$ & $(0.0018)$ & 0.001 & $(0.0006)$ \\
\hline SIZE & -0.011 & $(0.0360)$ & 0.003 & $(0.0398)$ & 0.002 & $(0.0431)$ & 0.025 & $(0.0432)$ & 0.022 & $(0.0370)$ & 0.003 & $(0.0023)$ \\
\hline HIGH-TECH & $4.889^{* * *}$ & & 4.914 & $(4.4232)$ & $4.780^{* * *}$ & & $4.862^{* * *}$ & & $4.894^{* * *}$ & & $5.276^{* * *}$ & \\
\hline Hypothesized effects & & & & & & & & & & & & \\
\hline $\begin{array}{l}\text { REG R\&D } \\
\text { EXPEND }\end{array}$ & & & 0.000 & $(0.0011)$ & & & & & & & $0.001^{*}$ & $(0.0006)$ \\
\hline REG R\&D STAFF & & & & & -0.331 & $(0.3379)$ & & & & & -0.006 & $(0.0078)$ \\
\hline $\begin{array}{l}\text { REG HUMAN } \\
\text { CAPITAL }\end{array}$ & & & & & & & -0.001 & $(0.0004)$ & & & -0.001 & $(0.0003)$ \\
\hline REG PATENT & & & & & & & & & -0.023 & $(0.0196)$ & 0.006 & $(0.0032)$ \\
\hline $\begin{array}{l}\text { Likelihood-ratio chi- } \\
\text { square }\end{array}$ & $55.975^{\star * *}$ & & $58.766^{* * *}$ & & $61.872^{* * *}$ & & $59.119^{* * *}$ & & $58.638^{* * *}$ & & $25.362^{* *}$ & \\
\hline
\end{tabular}

${ }^{* * *} \mathrm{p}<0.001 ;{ }^{* \star} \mathrm{p}<0.01 ;{ }^{*} \mathrm{p}<0.05$; (all two-tailed tests). Source: authors 


\section{Results discussion and conclusion}

The paper aimed to study the impact of some contextual determining factors on the innovation performance of USOs. In detail, and based on existing literature, it was stated that pivotal mechanisms both at university level and at regional level may positively influence the degree of innovativeness of the start-ups university. In order to test the developed hypotheses, a sample of 621 Italian USOs was investigated during an exploration period of nine years, from 2004 to 2012. The results show that the positive impact of the university context is more central and significant compared with those of the regional context. In particular, regarding the determining factors of the university level, the university affiliated to business incubators and Science Parks seems to have an effective and proactive impact on the innovation performance of USOs. These findings are in line with those of Soetanto and Jack (2015), remarking how the incubation support offered by the university is an essential and determining element of the effective innovation strategy, enhancing the full exploitation of USO innovation opportunities. Additionally, also the availability of suitable financial university resources contribute to improve the innovation efforts of USO; an evidence that emphasizes the role of university research funding, in innovative activities, with a more signal compared to the empirical findings, related to the role of the same mechanism in supporting the entrepreneurial success performance - not in term of innovation - of the spin-off, as reported in previous studies (Fini et al., 2011; Rodeiro-Pazos et al., 2012). Nevertheless, the role of technology transfer office seems to be a form of support not so active and imperative in ensuring an optimal exploitation of the innovative activities carried out by the USO. With particularly reference to the regional level determining factors, instead, the results indicate as their promoting impact on innovation performance of the USOs looks actually absent. Indeed, for the whole regional mechanisms, taken into account in the study, namely the regional R\&D activities, the regional human capital and the regional patenting activity, the empirical evidence reports a null effects, remarking as marginal or vague role of the local context in fostering the innovative efforts of the university start-ups. This is in contrast with the previous findings of Rodríguez-Gulías et al. (2015), which remark the pivotal role of regional condition to catalyse innovation in USOs, but also of those of Bellmann et al. (2013) for comparable companies. The reason beyond our empirical evidence may be potentially and partially due to the specific features of the Italian regional context, but also due at different evaluation of regional supporting factors compared with the previous studies. Regarding this last case, the study opens new issues to better asses the effective role of the regional context on the innovation performance of the USOs. The study has some interesting practical and policy implications. Due to the limited role of regional context in fostering innovation performance in USOs, in order to exploit all the potential innovative efforts of the university start-ups and better actualize their innovative strategies, it is essential a strong and collective partnership between all the regional players involved in the spillover and innovative processes. In detail, it is fundamental the function of local governments which have to act more as facilitators in the interchange of knowledge and technology, by scheduling strategy actions that identify the prominence of network and relationships, towards a new innovative regional environment. This is a key precondition in order to improve economic development, since the concept of "entrepreneur as innovator" is a key figure in driving growth, both at firm and regional-national level (Vincett, 2010). Nevertheless, the study is not free of limitations. The empirical study is based only on patent data as measure of USOs innovation, which can potentially undervalue the innovative performance of university start-ups, since not all innovation output are patented by USOs (Cantner \& Goethner 2011), also because of administrative restraints (Bellmann et al., 2013). Therefore, the developed model can be considered as a basic starting point with the aim to develop more extensive studies that are able to intercept, in a comprehensive and systemic way, the impact of contextual factors on USOs innovation. In this view, further researches could expand the evaluation of USOs activities into other indicators, related to innovation input, as R\&D intensity, a relevant proxy of firm innovative performance (De Cleyn \& Braet, 2012); jointly with the use of output measures of innovation (Hagedoorn \& Cloodt, 2003), as product and process innovation.

\section{References}

Acs, Z. J., Audretsch, D. B., \& Lehmann, E. E. (2013). The knowledge spillover theory of entrepreneurship. Small Business Economics, 41(4), 757-774.

Algieri, B., Aquino, A., \& Succurro, M. (2013). Technology transfer offices and academic spin-off creation: The case of Italy. The Journal of Technology Transfer, 38(4), 382-400.

Audretsch, D. B. (2003). Innovation and spatial externalities. International Regional Science Review, 26(2), 167-174.

Audretsch, D. B., \& Feldman, M. P. (2004). Knowledge spillovers and the geography of innovation. Handbook of regional and urban economics, 4, 2713-2739.

Audretsch, D. B., Bönte, W., \& Keilbach, M. (2008). Entrepreneurship capital and its impact on knowledge diffusion and economic performance. Journal of business venturing, 23(6), 687-698.

Baldini, N. (2010). University spin-offs and their environment. Technology Analysis \& Strategic Management, 22(8), 859-876.

Bellmann, L., Crimmann, A., Evers, K., \& Hujer, R. (2013). Regional determinants of establishments' innovation activities: a multi-level approach, IZA Discussion Papers. Institute for the Study of Labor (IZA).

Berbegal-Mirabent, J., Ribeiro-Soriano, D. E., \& García, J. L. S. (2015). Can a magic recipe foster university spin-off creation?. Journal of Business Research, 68(11), 2272-2278.

Beugelsdijk, S. (2007). The regional environment and a firm's innovative performance: A plea for a multilevel interactionist approach. Economic Geography, 83(2), 181-199. 
Cantner, U., \& Goethner, M. (2011). Performance differences between academic spin-offs and non-academic start-ups: A comparative analysis using a non-parametric matching approach. In Paper presented at the DIME Final Conference.

De Cleyn, S. H., \& Braet, J. (2012). Do board composition and investor type influence innovativeness in SMEs?. International Entrepreneurship and Management Journal, 8(3), 285-308.

Declercq, G. V. (1981). A Third Look at the Two Cultures: The New Economic Responsibility of the University. International Journal of Institutional Management in Higher Education, 5(2), 117-22.

Etzkowitz, H. (2002). Incubation of incubators: innovation as a triple helix of university-industry-government networks. Science and Public Policy, 29(2), 115-128.

Fini, R., Grimaldi, R., Santoni, S., \& Sobrero, M. (2011). Complements or substitutes? The role of universities and local context in supporting the creation of academic spin-offs. Research Policy, 40(8), 1113-1127.

Florida, R. (1995). Toward the learning region. Futures, 27(5), 527-536.

Florida, R. (2005). Cities and the creative class. Routledge.

Gittelman, M. (2007). Does geography matter for science-based firms? Epistemic communities and the geography of research and patenting in biotechnology. Organization Science, 18(4), 724-741.

Griliches, Z. (1990). Patent statistics as economic indicators: a survey. National Bureau of Economic Research.

Grimaldi, R., \& Grandi, A. (2005). Business incubators and new venture creation: An assessment of incubatingmodels. Technovation, 25(2), 111-121.

Guerini, M., \& Rossi-Lamastra, C. (2014). How university and industry knowledge interact to determine local entrepreneurship. Applied Economics Letters, 21(8), 513-516.

Hagedoorn, J., \& Cloodt, M. (2003). Measuring innovative performance: is there an advantage in using multiple indicators?. Research policy, 32(8), 1365-1379.

Iacobucci, D., \& Micozzi, A. (2014). How to evaluate the impact of academic spin-offs on local development: an empirical analysis of the Italian case. The Journal of Technology Transfer, 40(3), 434-452.

Kieschnick, R., \& McCullough, B. D. (2003). Regression analysis of variates observed on $(0,1)$ : percentages, proportions and fractions. Statistical modelling, 3(3), 193-213.

Lejpras, A. (2014). How innovative are spin-offs at later stages of development? Comparing innovativeness of established research spin-offs and otherwise created firms. Small Business Economics, 43(2), 327-351.
Lockett, A., Siegel, D., Wright, M., \& Ensley, M. D. (2005). The creation of spin-off firms at public research institutions: Managerial and policy implications. Research Policy, 34(7), 981-993.

Minguillo, D., \& Thelwall, M. (2015). Which are the best innovation support infrastructures for universities? Evidence from R\&D output and commercial activities. Scientometrics, 102(1), 1057-1081.

Montoro-Sánchez, A., Ortiz-de-Urbina-Criado, M., \& Mora-Valentín, E. M. (2011). Effects of knowledge spillovers on innovation and collaboration in science and technology parks. Journal of knowledge management, 15(6), 948-970.

Netval (2015), XII Rapporto Netval sulla Valorizzazione della Ricerca Pubblica Italiana "Protagonisti dellecosistema dell'innovazione?". Ramaciotti, L. \& Dianele, C. (a cura di). Network per la Valorizzazione della Ricerca Universitaria, Pavia.

O’shea, R. P., Allen, T. J., Chevalier, A., \& Roche, F. (2005). Entrepreneurial orientation, technology transfer and spinoff performance of US universities. Research policy, 34(7), 994-1009.

Pardo, J. A., \& Pardo, M. C. (2008). Minimum $\varphi$-divergence estimator and $\varphi$-divergence statistics in generalized linear models with binary data. Methodology and Computing in Applied Probability, 10(3), 357-379.

Pazos, D. R., López, S. F., González, L. O., \& Sandiás, A. R. (2012). A resource-based view of university spin-off activity: New evidence from the Spanish case. Revista Europea de Dirección y Economía de la Empresa, 21(3), 255-265.

Plewa, C., Troshani, I., Francis, A., \& Rampersad, G. (2012). Technology adoption and performance impact in innovation domains. Industrial Management \& Data Systems, 112(5), 748-765.

Plummer, L. A., \& Acs, Z. J. (2014). Localized competition in the knowledge spillover theory of entrepreneurship. Journal of Business Venturing, 29(1), 121-136.

Rasmussen, E., Mosey, S., \& Wright, M. (2014). The influence of university departments on the evolution of entrepreneurial competencies in spin-off ventures. Research Policy, 43(1), 92-106.

Raspe, O., \& Van Oort, F. G. (2008). Firm growth and localized knowledge externalities. Journal of Regional Analysis and Policy, $38(2), 100-116$.

Rodeiro-Pazos, D., Rodriguez-Gulías, M.J., \& Fernandez-López, S. (2014). La actividad de innovación en lasspin-offs universitarias. Existe alguna diferencia con el resto de empresas? In A. G. Aracil, \& I.

N. Gómez (Eds.), Investigaciones de Economía de la Educación, 9 (pp. 241 - 253). Valencia: Jornadas de la Asociación de Economía de la Educación. 
Rodríguez-Gulías, M. J., Rodeiro-Pazos, D., \& Fernández-López, S. (2015). The regional effect on the innovative performance of University spin-offs: a multilevel approach. Journal of the Knowledge Economy, 1-21.

Shane, S. A. (2004). Academic entrepreneurship: University spinoffs and wealth creation. Edward Elgar Publishing.

Sirmon, D. G., Hitt, M. A., \& Ireland, R. D. (2007). Managing firm resources in dynamic environments to create value: Looking inside the black box. Academy of management review, 32(1), 273-292.

Soetanto, D., \& Jack, S. (2015). The impact of university-based incubation support on the innovation strategy of academic spin-offs. Technovation. In press.

Sørensen, J. B., \& Stuart, T. E. (2000). Aging, obsolescence, and organizational innovation. Administrative science quarterly, 45(1), 81-112. Sternberg, R. (2014). Success factors of university-spin-offs: Regional government support programs versus regional environment. Technovation, 34(3), 137-148.

Van Looy, B., Landoni, P., Callaert, J., van Pottelsberghe, B., Sapsalis, E., \& Debackere, K. (2011). Entrepreneurial effectiveness of European universities: An empirical assessment of antecedents and trade-offs. Research Policy, 40(4), 553-564. van Oort, F. G., Oud, J. H., \& Raspe, O. (2009). The urban knowledge economy and employment growth: a spatial structural equation modeling approach. The Annals of Regional Science, 43(4), 859-877.

Vincett, P. S. (2010). The economic impacts of academic spin-off companies, and their implications for public policy. Research Policy, 39(6), 736-747.

Vinig, G. T., \& Van Rijsbergen, P. J. (2010). Determinants of university technology transfer-a comparative study of US, European and Australian Universities. In A. Malach-Pines (Ed.), Handbook of research on high technology entrepreneurship. Edward Elgar.

Vinig, T., \& van Rijsbergen, P. (2010). 10 University technology transfer: comparative study of US, European and Australian universities. Handbook of Research on High-Technology Entrepreneurs, 179.

Wong, P. K., Ho, Y. P., \& Autio, E. (2005). Entrepreneurship, innovation and economic growth: Evidence from GEM data. Small Business Economics, 24(3), 335-350.

Wood, M. S. (2011). A process model of academic entrepreneurship. Business Horizons, 54(2), 153-161.

Wright, M., Clarysse, B., Mustar, P., Lockett, A., 2007. Academic entrepreneurship in Europe. Cheltenham: Edward Elgar, p. 228. 